\title{
Introducing Epiphanies
}

\author{
Sophie Grace Chappell
}

Published online: 21 June 2019

(C) The Author(s) 2019

\begin{abstract}
I propose a programme of research in ethical philosophy, into the peak-experiences or wow-moments that I, following James Joyce and others, call epiphanies. As a first pass, I characterize an epiphany as an (1) overwhelming (2) existentially significant manifestation of (3) value, (4) often sudden and surprising, (5) which feels like it "comes from outside" - it is something given, relative to which I am a passive perceiver - which (6) teaches us something new, which (7) "takes us out of ourselves", and which (8) demands a response. Often the correct response is love, often it is pity, or again creativity. It might also be anger or reverence or awe or a hunger to put things right - a hunger for justice; or many other things. It may be something that leads directly to action, but it may also be something that prompts contemplation; or other responses again. Since epiphanies are what I call a focalcase category, not all of the conditions listed above have to be fulfilled by all instances of epiphanies. In order to allow the reader to get a better grip on which range of phenomena may count as an epiphany, I examine in some detail several examples from literature, in particular from works by Murdoch, Hopkins, Wordsworth, C.S. Lewis, and by James Joyce.
\end{abstract}

Keywords Epiphanies · Ethics · Anti-theory · Murdoch · Hopkins · Wordsworth · C.S. Lewis · James Joyce

S. G. Chappell ( $\square)$

The Open University, Milton Keynes, UK

E-Mail: Sophie-grace.chappell@ open.ac.uk 
1

One day during my last term at school I walked out alone in the evening and heard the birds singing in that full chorus of song, which can only be heard at that time of the year at dawn or at sunset. I remember now the shock of surprise with which the sound broke on my ears. It seemed to me that I had never heard the birds singing before and I wondered whether they sang like this all year round and I had never noticed it. As I walked I came upon some hawthorn trees in full bloom and again I thought that I had never seen such a sight or experienced such sweetness before. If I had been brought suddenly among the trees of the Garden of Paradise and heard a choir of angels singing I could not have been more surprised. I came then to where the sun was setting over the playing fields. A lark rose suddenly from the ground beside the tree where I was standing and poured out its song above my head, and then sank still singing to rest. Everything then grew still as the sunset faded and the veil of dusk began to cover the earth. I remember now the feeling of awe which came over me. I felt inclined to kneel on the ground, as though I had been standing in the presence of an angel; and I hardly dared to look on the face of the sky, because it seemed as though it was but a veil before the face of God. (Griffiths 1979, 9)

I am looking out of my window in an anxious and resentful state of mind, oblivious of my surroundings, brooding perhaps on some damage done to my prestige. Then suddenly I observe a hovering kestrel. In a moment everything is altered. The brooding self with its hurt vanity has disappeared. There is nothing now but kestrel. And when I return to thinking of the other matter it seems less important.

(Murdoch 1970, 84)

I caught this morning morning's minion, king-

dom of daylight's dauphin, dapple-dawn-drawn Falcon, in his riding

Of the rolling level underneath him steady air, and striding

High there, how he rung upon the rein of a wimpling wing

In his ecstasy!

(Hopkins 1967, 69)

Together these three striking passages point to my present research topic. No, not birds; all three of these passages do, as it happens, feature birds, but that is not why I quote them. My interest in them is that they all report what I shall call epiphanies.

What is an epiphany? When people who aren't academic philosophers ask me what I do, and I tell them that my current research project is about epiphanies, they usually know immediately - as immediately as they would if I was writing about birds - what I'm talking about. Or at least, they know as soon as I drop the technical and religious-sounding term "epiphany", and talk about "wow-moments" and "ahamoments" and "eureka moments" and "peak experiences" instead. Epiphanies are experiences like the three just quoted, and the testimony of those around me, at any rate, is that such experiences are a very common part of people's lives. 
So we can (begin to) explain what an epiphany is by saying "an experience like that", and pointing the inquirer to examples like the three above. Or if we want a verbal definition of "epiphany", we might be satisfied with some (at any rate) of what the American dictionary Merriam-Wester has to say:

\section{epiphany plural epiphanies}

1 capitalized: January 6 observed as a church festival in commemoration of the coming of the Magi as the first manifestation of Christ to the Gentiles or in the Eastern Church in commemoration of the baptism of Christ

2: an appearance or manifestation especially of a divine being

3a (1): a usually sudden manifestation or perception of the essential nature or meaning of something

(2): an intuitive grasp of reality through something (such as an event) usually simple and striking

(3): an illuminating discovery, realization, or disclosure

3b: a revealing scene or moment

(Merriam-Webster's Dictionary online, https://www.merriam-webster.com/ dictionary/epiphany)

Epiphanies in the sense I'm concerned with are covered mainly by (3a) and (3b) of this dictionary entry. ((2) will be relevant also, at any rate if the "appearance or manifestation" of the "divine being" is, well, epiphanic.)

For a definition of "epiphany" that is more customised to my present purposes we can say this, at least as a first pass:

An epiphany is an overwhelming existentially significant manifestation of value, often sudden and surprising, which feels like it "comes from outside" - it is something given, relative to which I am a passive perceiver - which teaches us something new, which "takes us out of ourselves", and to which there is a natural and correct response. (At least one; possibly more.) Often the correct response is love, often it is pity, or again creativity. ${ }^{1}$ It might also be anger or reverence or awe or a hunger to put things right - a hunger for justice; or many other things. It may be something that leads directly to action, but it may also be something that prompts contemplation; or other responses again.

That is only a first pass, because in fact epiphanies are what I shall call a focalcase category. There are clear and central cases of epiphanies, like the three I list above. But there are also less clear and less central cases, which we might still want to call epiphanies; or there again, might not. Nothing much turns on where exactly we draw the boundaries around the proper use of the term "epiphany". The central territory of the concept is not threatened by minor demarcation disputes about its borders. There are certainly grey areas, and they certainly have their interest. There are equally certainly non-grey areas: for instance, the black ones and the white ones. And those are my main concern here. True, there are no non-stipulative necessary and sufficient conditions for something's being an epiphany, and the epiphanic fades out, around its edges, into relatively unexciting or small-scale phenomena like the

\footnotetext{
1 To my mind these are the three great virtues.
} 
merely striking or surprising moment. There are no non-stipulative necessary and sufficient conditions for something's being a mountain, either, and the category of the mountainous too fades out around its edges into literally small-scale phenomena. That does not stop the geologist from studying mountains, nor the alpinist from climbing them.

Again it might be said that, if epiphanies are the peaks in our experience, then by definition, to study them must also be to study the troughs. Quite true, and I shall consider the troughs in due course. But this kind of expansionism about my subjectmatter does not worry me. In fact I endorse it myself, for at least two reasons.

First because, as we shall see, there is not just one peak/trough contrast in question. Our experience can be epiphanic by reaching a peak of delight; or of vividness; or of forcefulness or intensity; or of lucidity; or of horror, or of terror, or of anger; and in other ways too. I began, above, with three cases of peak experiences of delight in nature - all involving birds - but all sorts of other kinds of experiential peaks might reasonably be called epiphanic too; and there are, as I say, plenty more examples of very various kinds to come. That is not a problem for my inquiry; it is a ground condition for it.

And secondly because, as this perhaps suggests, my real interest is in the entire experiential continuum in which epiphanies are the peaks. The real object of my inquiry into epiphanies is not just epiphanies, but all of the plenum of lived experience of which they are parts: the peaks and the troughs (in their manifold kinds), and everything in between as well. Talking about epiphanies is a good way into this wider inquiry into our lived experience; but in the end, it is only a way into it. The peaks in our experience could not be peaks unless there was a longer, wider story about what they are peaks in. This is obviously so with my three initial examples. Murdoch's and Hopkins' encounters with their hawks are to be understood against the backdrop of a preceding narrative; Griffiths' encounter, explicitly, precedes a succeeding narrative, namely the autobiography that it begins. In all three cases "story" is exactly the word for the larger framework that makes sense of and gives their full significance to these three epiphanies. Unavoidably, then, and in no way regrettably, it is not just the epiphanies themselves but their wider contexts that really matter. So what I am really looking to develop in my research is not just an ethics of epiphanies, but (as my subtitle suggests) an ethics of the phenomena of lived experience as a whole: an ethics of sensibility, an ethics of what it's like to be a human.

For now I note simply that the phenomena of lived experience are messy, and one thing blurs into another. This messiness is reflected, deliberately, in my account, on which an epiphany is, as I say above, “(1) an overwhelming (2) existentially significant manifestation of (3) value, (4) often sudden and surprising, (5) which feels like it 'comes from outside' - it is something given, relative to which I am a passive perceiver - (6) which teaches us something new, which (7) takes us 'out of ourselves', and which (8) demands a response". These numbers indicate how my first-pass definition gives us at least eight directions in which there can be shadingsoff from, or further specifications of, focal cases like the three examples that I started with. 
Here's one direction of shading-off: my definition deploys the concepts (3) value and (8) response, but in all three of the examples that I started with, the roles of these two concepts are played by two more specific things, the value beauty and the response love. Bede Griffiths' and Iris Murdoch's and Gerard Manley Hopkins' experiences are all experiences of a particular kind of value, namely beauty; and this kind of value prompts a particular kind of response from them, namely love. In these cases there is what we might call an apt-response connection - and so, a conceptual connection - between beauty and love.

It's important to note straight away that epiphanies can deserve the name without being of beauty, and without involving a response of love. They can for instance be of what Burke and Kant called the sublime, or of the awesome, the spectacular, the scary; to which some modulation of fear is an entirely reasonable response. Or again, they can be of the true or the vitally important (for example, as with Saul on the road to Damascus, the salvific), or even of the harrowing or the horrible: and in none of these cases is love exactly the best word to describe the most apt response to the epiphanies in question. To some epiphanies terror or outrage or tears of repentance, or a three-day blind fast (St Paul again: Acts 9.9), can be a perfectly proper reaction. Beauty and love are the right words for the experience and the apt response in some cases of epiphany. But not all. Typical epiphanies are those points in the continuum of lived experience where we undergo sharp and particular cases of encounter with value; but they are not the only cases of encounter with value, and the latter category, which is broader and wider, has an interest of its own.

Again, focal-case epiphanies are so big as to be (1) overwhelming and (2) existentially significant. But as we move away from the focal cases, epiphanies shade off towards the small (only minor high-points in our lived experience, hillocks not Himalayas) and so towards the far from overwhelming. When epiphanies are less than overwhelming, their existential significance may seem to be in doubt as well. I walk into the kitchen and through the window I see one vivid blue cyanothus flower in the sunny green garden outside. It's a beautiful sight, but it's only a little thing. It's a delightful experience, but not an overwhelming one; it's too small for that. So, being small, maybe it's not especially existentially significant. And (6) maybe it teaches me nothing new, either. (Maybe not. Though there can be large-scale things to be learned from small-scale raptures like this, as a variety of religious teachers in traditions from Zen to the Franciscans and the Quakers have insisted. Perhaps the same insistence is implicitly there in the Dutch still-life school of painting, with its famous "transfiguration of the commonplace" (Danto 1983).) Nor (7) does it take me "out of myself" into anything like the Greek for that state, ecstasy. It's just, as the English say, awfully nice. A happy life is thick with such small gratuitous delights, shading over the border of the apt use of the word "epiphany" into still smaller and more mundane pleasures like the smell of fresh-ground dark-roast coffee in the morning.

With small epiphanies like the cornflower, there is an interesting question just how much responsiveness to them is appropriate. There is such a thing as being boorishly under-sensitive to the beauty around us, but a moment's thought about life's practicalities suggests that there may be such a thing as being over-sensitive 
too. Though the most interesting worry here is not that one might be over-sensitive by being an inaccurate sensor of value, but precisely by being an accurate one:

That element of tragedy which lies in the very fact of frequency, has not yet wrought itself into the coarse emotion of mankind; and perhaps our frames could hardly bear much of it. If we had a keen vision and feeling of all ordinary human life, it would be like hearing the grass grow and the squirrel's heartbeat, and we should die of that roar which lies on the other side of silence. As it is, the quickest of us walk about well wadded with stupidity. (Eliot 1872, 194)

If, as for most people most of the time, there are things that I need to get on with today, then at least usually it had better not be the case that "To me the meanest flower that blows can give/ Thoughts that do often lie too deep for tears." The richness of reality can be overwhelming; and often the cognitive difficulty is evidently not so much to grasp it, as to avoid grasping too much of it. To get on with the quotidian, we need to filter the epiphanic. (More about this point, and the demandingness worry that it might suggest, in 3.7.)

In The Doors of Perception (Huxley 1954, 22-24) Aldous Huxley, with a quotation from Broad, takes the same idea further - perhaps too far:

Reflecting on my experience, I find myself agreeing with the eminent Cambridge philosopher, Dr. C.D. Broad, ${ }^{2}$

that we should do well to consider much more seriously than we have hitherto been inclined to do the type of theory which Bergson put forward in connection with memory and sense perception. The suggestion is that the function of the brain and nervous system and sense organs is in the main eliminative and not productive. Each person is at each moment capable of remembering all that has ever happened to him and of perceiving everything that is happening everywhere in the universe. The function of the brain and nervous system is to protect us from being overwhelmed and confused by this mass of largely useless and irrelevant knowledge, by shutting out most of what we should otherwise perceive or remember at any moment, and leaving only that very small and special selection which is likely to be practically useful.

According to such a theory, each one of us is potentially Mind at Large. But in so far as we are animals, our business is at all costs to survive. To make biological survival possible, Mind at Large has to be funnelled through the reducing valve of the brain and nervous system. What comes out at the other end is a measly trickle of the kind of consciousness which will help us to stay alive on the surface of this particular planet... [What], in the language of religion, is called "this world" is the universe of reduced awareness, expressed and, as it were, petrified by language. The various "other worlds" with which human beings erratically make contact are so many elements in the totality of the awareness belonging to Mind at Large.

For a more recent example of a philosopher who takes brain activity to be more about selection than absorption, though without Huxley's very strong claims about an

\footnotetext{
2 See Broad (1949, 306). Thanks to Nicholas Denyer for reminding me of the Huxley passage.
} 
initial or potential awareness of everything, take Andy Clark's notion of "predictive processing":

...the brain... focussed on the most urgent or worrying or puzzling facts: those which indicated something unexpected. Instead of taking in a whole scene afresh each moment, as if it had never encountered anything like it before, the brain focussed on the news: what was different, what had changed, what it didn't expect. The brain predicted that everything would remain as it was, or would change in foreseeable ways, and when that didn't happen error signals resulted. As long as the predictions were correct, there was no news. But if the signals appeared to contradict the predictions - there is a large dog on your sofa (you do not own a dog) - prediction-error signals arose, and the brain did its best to figure out, as quickly as possible, what was going on. ${ }^{3}$

Much that is at least potentially epiphanic in our lived experience never makes it into explicit consciousness because it is never attentionally selected. ${ }^{4}$

For a further example, consider this autobiographical snippet. In Scotland the latitudes are high but the mountains are not, and so a winter-climber's day normally ends with getting home. But in April 2008 I had a climbing accident on Zero Gully on Ben Nevis that kept me in hospital for 20 days. I longed to get out of hospital and simply go home, in the way I'd expected to before the accident happened. And I noticed what I'd never noticed before - how much pleasure it gives me every single time I walk up my own garden path and come in through my own front door. Sensory deprivation can sharpen sensory sensitivity, so that in a deprived state such as a hospital bed we notice beauties around us that normally we just pass by, registering them all right, but only subliminally. So perhaps we are, or at least the lucky ones of us are, so surrounded by small epiphanies that, for extraneous reasons such as the conscious mind's editing functions, most of them don't even make it into our awareness - which of course is consistent with us getting a lot from them subconsciously.

Another way in which we move easily away from the paradigm cases is that epiphanies aren't always (4) either sudden or surprising. Suppose (mountaineering again) that you're an Alpine guide, and you've been guiding the Matterhorn for 20 years. On a still cold clear morning of the kind that you need to climb the Matterhorn safely (or as safely as can be), you know exactly what it's going to be like when the dawn comes as you reach the Shoulder. Indeed, since you are careful about guidebook times, you know pretty well exactly where on the Shoulder you will be when the dawn arrives. So you've seen this very dawn dozens of times before. It is magnificent, and it does you good, and it is undeniably an epiphany. But it's not new, and not surprising either; if it (6) teaches you anything, it is a lesson you have had many times before. It happens exactly as you expect it to - to your delight. Here we are close, again, to the idea of being under-sensitive to epiphanic experience, to the idea of being blasé. But only close, not actually there.

\footnotetext{
3 McFarquhar (2018).

4 For more thoughts about attention from a great pioneering psychologist-philosopher, see William James' Principles of Psychology (James 1890, vol. 1, ch. XI).
} 
So epiphanies can teach you something new, or they can just remind you afresh of what you know already; very likely they can affect us subliminally too. Another dimension of variation is that they can be more or less cognitively loaded, and this in a whole variety of ways.

One established use of the term "epiphany" (not my own focal use, but I have no wish to legislate against it) is to talk about epistemic breakthroughs. For example, a scientist might suddenly just see, maybe in a dream, what the structure of the benzene molecule must be - so Friedrich Kekule's famous dream of the snake with its tail in its mouth. This epistemic sense is stronger in the Merriam-Webster definition that I take as one of my epigraphs, which makes epiphanies not so much wow-moments as aha-moments. However, just by stipulation if need be, I'll say that such cases aren't central to what I'm talking about; at least to begin with, I am more focused on wow-moments than aha-moments.

Epiphanies as wow-moments are still usually cognitively loaded in the different sense, already noted above, that they typically fit more or less into a background narrative. This background narrative may be an "erotetic" one in Robin Collingwood's sense (Collingwood 1939, 36-37), a kind of question-and-answer sequence: in which the epiphanies we have make the sense that they do because they give the answer to some question that we're asking. This is one of the ways by which epiphanies come to have existential significance, to contribute to "the meaning(fulness) of life". Another is that they can answer a question we're not asking, but the epiphany shows us we should be. Or again, an epiphany can lead us to question our very questions; or in all sorts of other possible ways lead to large-scale cognitive and existential reframing. In the end we can get to the aha-moment sense of epiphany from the wowmoment sense - and maybe we can work in the other direction too. (One possible bridge between them is the notion of an aspect change or gestalt switch. ${ }^{5}$ ) Still, it's the wow-moment sense that concerns me here, at least for now.

But there is also the possibility of an epiphany that isn't very cognitively loaded at all. It's just there, and beautiful, and undoubtedly existentially significant, as I put it above. Yet who knows what it means? And as subjects of such experiences are often inclined to ask, what should it matter what it means? The point is the epiphany, not some interpretation of the epiphany. Its significance is just itself, and not any further words whatever.

This possibility brings home a further important point: that an epiphany could strike us as deeply existentially significant, yet have no clear propositional meaning. I think it is like this with a lot of art, particularly perhaps pure music. Its significance is "beyond verbal articulation", "ineffable"; or so we usually say. Yet even those words are not quite the right ones. It's not that there is something to be said to express the meaning of the artwork, if only we had the words to say it. It's rather that the significance of the artwork is just not propositional at all. The artwork is itself, not an encoding of a secret message. Or, another possibility, the artwork invites a variety of interpretations; but no one of those is the correct interpretation - many of them are revealing in one way or another, but none of them is final, conclusive, or exhaustive.

\footnotetext{
5 Thanks to Sasha Lawson-Frost for reminding me of this.
} 
This possibility - the possibility of icons, as I shall call them - is I think an important and philosophically fruitful idea. One thing it helps to move us towards is a clearer conception of what it might be for knowledge to be objectual rather than propositional. We should take seriously the possibility of a form of epiphany maybe it is the highest form, or close - that just is awareness of a reality, cognitively loaded, but where the cognition is objectual knowledge not propositional knowledge. I take this possibility very seriously indeed, though I only point to it here.

A different dimension of variation for epiphanies which is worth getting onto the agenda at once is whether they are shared or solitary, individual experiences or communal ones. On this issue we are under the immense cultural influence of the Romantics: consider the subtitle of Wordsworth's Prelude, "Growth of a poet's mind" (note the singular), or his "I wandered lonely as a cloud". Thanks to them, we find it natural to see the sublime as primarily egotistical (that being, since Keats, the standard derogatory about Wordsworth: see 1.5), and to think of the wow-moment as primarily some one person's wow-moment. But there is no necessity about this. Historically our culture is a culture of churches and theatres and parliaments and university disputations and courts (of law, of kings, and of tennis). It has always recognised the possibility of epiphanies which are constitutively communal and shared. Anyone who has been to a rock concert, a sports match, or even a crowded cinema or theatre, knows that such shared epiphanies continue to happen in the present, indeed are in many ways a more striking feature of our culture today than ever before (Chappell 2011).

One faulty line of reasoning to the conclusion that epiphanies must always, or at any rate primarily, be solitary ecstasies points to the supposed necessity of individual experience as a precondition for communal experience. Someone might insist that there can be no social knowledge without prior individual knowledge, "because all social knowledge would have to be stored first in individual minds". The argument is no better in the case of epiphanies than it is in the case of social epistemology. For one thing, what gets to the individual mind is necessarily and essentially shaped, before it gets there, by its trajectory through social space. For another, the argument seems to commit a part-whole fallacy of some sort. No one thinks of arguing that since company A cannot buy company B without an executive from A who signs on a dotted line to validate a legal contract, therefore it is really not company A but that executive who buys B. Likewise, no one should argue that social knowledge, or experience, cannot be truly social just because it is grounded, or perhaps we should rather say represented, in individual consciousnesses.

A second bad line of reasoning to the conclusion that epiphanies must be always or primarily individual relies on the (perfectly true) thought that they are clear instances of what Hans Urs von Balthasar, following Hegel's lectures on aesthetics, would call "the lyrical" rather than "the epic" or the "dramatic". ${ }^{6}$ In this triadic distinction of ways of narrating or of being a poet, "the epic" fixes the grand récit, the long broad sweep of history, and does so from a high and remote viewpoint, like that of Homer's

\footnotetext{
${ }^{6}$ Hegel (1835); von Balthasar (1988, Vol II); Wells (2004, 46-57).
} 
gods in the Iliad. ${ }^{7}$ By contrast, "the lyrical" pinpoints the sharp particularity of the momentary experience, with maximum subjectivity and personal involvement; and "the dramatic" is the synthesis of the epic and the lyrical. Like any true Hegelian synthesis, the dramatic gets the best of both its thesis' and its antithesis' worlds, and the worst of neither: it preserves the presence-in-the-moment of the lyrical without getting submerged in that moment, and it preserves the Olympian perspective of the epic without retreating to Olympus.

No doubt, in these terms, most of us have a natural tendency towards either the lyrical or the epic; no doubt - moral particularists perhaps aside - epic is the prevailing tendency in contemporary analytic philosophy; and no doubt it is partly my own tendency towards the lyrical that makes the topic of epiphanies so appealing to me. Be that as it may, it is natural to see this Hegelian triad as working in harness with two others, the triad that goes impersonal/ personal/ communal, and the triad that goes state-of-nature/ individual/ political; and all of that leads naturally to the conclusion that the lyrical is characteristically individual. But lyrical experiences can be shared and public too, and it is not only the possibility that Hegel points to, the possibility of drama, that guarantees that result. Certainly epiphanies that were originally private experiences can become public via drama; but some epiphanies, as above, were not private experiences even originally.

Epiphanies then can be private or public, communal or individual, cognitive or contentless, epistemic or aesthetic or moral, conscious or subconscious, and many other things besides. The category is broad, and open-edged, and even messy. If it is organised around anything, it is organised around phenomena like the three paradigm examples of epiphanies that I gave at the beginning. But it is not crucial to my purposes, at any rate, that the category should be highly organised. "Epiphanies" is my name for the peak experiences in our ethical life (that is, in our life). My main concern, as I've said, is the phenomenology of our life taken as a whole: including those peaks, but including the troughs and the slopes as well.

\section{2}

In order to understand adequately what epiphanies are, not just by abstract knowledge of a verbal definition but by experiential knowledge - first- or second-hand we need to have a good range of examples before us. So I collect and discuss some more examples of epiphanies to go alongside the initial three that I have already offered. (And are these focal cases of epiphanies? That question is worth keeping in mind as you read on.) The examples I will discuss here are drawn from Murdoch, Hopkins, and Wordsworth (3), from C.S. Lewis (4), and from James Joyce (6).

One point that I have already hinted at, and which will also emerge very clearly from this catalogue of epiphanies, is that there are indefinitely many ways of making theoretical sense of them. Much depends on the background of presuppositions, and in particular the pre-existing narrative framework, within which epiphanies are

\footnotetext{
7 Perhaps the most famous expression of the Homeric gods' detachment is Zeus at Iliad 13.1-9 (he turns away from the wearisome battles at Troy to survey, instead, the delightful sight of the furthest Mysians).
} 
received. This point will need to be kept constantly in mind as I myself attempt to make theoretical sense of epiphanies in later work. ${ }^{8}$

Because the rest of this paper is about examples of epiphanies, it will necessarily involve a good deal of quotation, and this may turn it into a rather bitty catalogue. Many of my quotations, moreover, will be of poetry. For poetry surely does have a privileged place in the discussion of epiphanies, since the preservation of epiphanies (among other experiences) is precisely what poetry is for. Or so it can be claimed, as it is for instance by Philip Larkin:

The short answer is that you write because you have to. If you rationalize it, it seems as if you've seen this sight, felt this feeling, had this vision, and have got to find a combination of words that will preserve it by setting it off in other people. The duty is to the original experience. It doesn't feel like self-expression, though it may look like it. As for whom you write for, well, you write for everybody. Or anybody who will listen. (Larkin 1982)

Not, as I think Larkin would agree, that this holds just for poets; it holds for novelists too.

\section{3}

I begin this catalogue of examples by revisiting the first one that I gave, Iris Murdoch's "There is nothing now but kestrel". Experiences something like this must be familiar to many people: a sudden encounter with something transcendently beautiful, and sublimely distanced from us and our busy concerns, "takes us out of ourselves" - a phrase that Murdoch takes pretty literally, seeing the encounter that she describes as something like a Buddhist moment of unselving. ${ }^{9}$

It is impossible to tell, and not all that important, whether Murdoch's case is actually autobiographical, as seems quite likely given her vivid description of it, or whether she builds it on other people's descriptions, or a bit of both. What is clear is that her words recall a second vivid encounter with a hawk which Murdoch almost certainly knew about: the one described in my second quotation in 1, from Gerard Manley Hopkins' "The Windhover". Let me quote the whole sonnet this time:

I caught this morning morning's minion, king-

dom of daylight's dauphin, dapple-dawn-drawn Falcon, in his riding

Of the rolling level underneath him steady air, and striding

High there, how he rung upon the rein of a wimpling wing

In his ecstasy! then off, off forth on swing,

As a skate's heel sweeps smooth on a bow-bend: the hurl and gliding

Rebuffed the big wind. My heart in hiding

Stirred for a bird, - the achieve of, the mastery of the thing.

\footnotetext{
8 Some of this is already available in draft on academia.edu.

${ }^{9}$ For a clear and interesting exposition of one Buddhist view of the ego and of enlightenment (satori, kensho), see Trungpa (1973, esp. $121 \mathrm{ff}$.$) .$
} 
Brute beauty and valour and act, oh, air, pride, plume, here

Buckle! AND the fire that breaks from thee then, a billion

Times told lovelier, more dangerous, O my chevalier!

No wonder of it: shéer plód makes plough down sillion

Shine, and blue-beak embers, ah my dear,

Fall, gall themselves, and gash gold-vermilion.

(Hopkins 1967, 69)

Hopkins is stirred to delight by something dashing, chivalric, glorious, masterful; his fine poem carries an erotic charge in a way that Murdoch's stiller, simpler, more limpid description does not. The object of this charged delight is, as very often with Hopkins, essentially masculine: a "brute beauty" in more than one sense of "brute".

Of course Hopkins is not likely to agree with Murdoch - not at least without a lot of qualification - on the Buddhist notion that there is a positive value in "unselfing". As he says in "Kingfishers catch fire", the good thing, for him as a Scotist, is to become more oneself, not less.

Each mortal thing does one thing and the same:

Deals out that being indoors each one dwells;

Selves - goes itself; myself it speaks and spells,

Crying Whát I dó is me; for that I came.

Yet for Hopkins as for Murdoch, the point of the hawk epiphany is still that it "takes him out of himself"; there remains a contrast between the moment of vision in which he beholds the hawk, and the "sheer plod" that we know from his journals was Hopkins' lot in so much of the difficult life that he chose for himself. Though Hopkins also makes, in the poem's somewhat obscure ending, a further point: that "sheer plod", uninspired effort, is itself at least part of the reason why the plough so shines as it moves down the furrow (sillion - the more you look at this poem, the more densely you see it is loaded with a chivalric or feudal vocabulary-cloud of French words). The contrast with the unepiphanic - Hopkins means - is itself crucial to yielding the epiphanic; months or years of preceding blankness can go into producing the moment of vision.

My next item is from Wordsworth's Prelude Book XII, lines 176-225 (Wordsworth 1984, 564f.); apologies for the length of this quotation. I call it an item rather than an example because it is not so much a description of a single epiphany, though there are plenty of those in Wordsworth too - see below, on "Daffodils" - as a reflection on the notion of an epiphany. (As the passage shows, the notion of an epiphany is there in Wordsworth, even if the word isn't.) In this passage the last thought of Hopkins' poem - that the unepiphanic can itself be a crucial part of what generates the epiphanic - is not presented; Wordsworth apparently sees the unepiphanic simply and unqualifiedly as an enemy of promise. But the more basic thought, about the contrast between the epiphanic and the unepiphanic, most certainly is present:

I loved whate'er I saw: nor lightly loved,

But most intensely; never dreamt of aught 
More grand, more fair, more exquisitely framed

Than those few nooks to which my happy feet

Were limited. I had not at that time 180

Lived long enough, nor in the least survived

The first diviner influence of this world,

As it appears to unaccustomed eyes.

Worshipping them among the depth of things,

As piety ordained, could I submit

To measured admiration, or to aught

That should preclude humility and love?

I felt, observed, and pondered; did not judge,

Yea, never thought of judging; with the gift

Of all this glory filled and satisfied 190

And afterwards, when through the gorgeous Alps

Roaming, I carried with me the same heart:

In truth, the degradation - howsoe'er

Induced, effect, in whatsoe'er degree,

Of custom that prepares a partial scale

In which the little oft outweighs the great;

Or any other cause that hath been named;

Or lastly, aggravated by the times

And their impassioned sounds, which well might make

The milder minstrelsies of rural scenes 200

Inaudible - was transient; I had known

Too forcibly, too early in my life,

Visitings of imaginative power

For this to last: I shook the habit off

Entirely and for ever, and again

In Nature's presence stood, as now I stand,

A sensitive being, a 'creative' soul.

There are in our existence spots of time,

That with distinct pre-eminence retain

A renovating virtue, whence - depressed

By false opinion and contentious thought,

Or aught of heavier or more deadly weight,

In trivial occupations, and the round

Of ordinary intercourse - our minds

Are nourished and invisibly repaired;

A virtue, by which pleasure is enhanced,

That penetrates, enables us to mount,

When high, more high, and lifts us up when fallen.

This efficacious spirit chiefly lurks

Among those passages of life that give 220

Profoundest knowledge to what point, and how,

The mind is lord and master - outward sense

The obedient servant of her will. Such moments 
Are scattered everywhere, taking their date

From our first childhood.

Given a suitably disposable copy of the text, we could go through these lines with scissors and paste, and cut into two separate piles the parts where Wordsworth talks about the epiphanic, and those where he talks about the unepiphanic. In childhood, he says (lines 181-2), he had not survived "the first diviner influence of this world"; the word-choice is ironic, of course, as if such a "survival" were a growth or a maturing of the spirit rather than its fading into visionless banality. Part of his diagnosis of what kills or degrades the immediacy of experience is "judgement" and "measurement", inasmuch as both of them are the servants of "custom that prepares a partial scale/ In which the little oft outweighs the great" (lines 196-7). In this talk of refusing to judge we are close to Wordsworth's own "we murder to dissect", ${ }^{10}$ and also to Keats's famous notion of "negative capability"; 11 in his rejection of "measured admiration" the allusion to Bentham, and to Plato's Protagoras behind Bentham, seems clear.

The thought of lines 208-218 is that such epiphanies, such "spots of time", have the power to overcome everything in our lives that makes for banality and triviality; for the unepiphanic. They "renovate" us, they set us free from the enemies that Wordsworth so clearly identifies, the forces that leave us depressed

By false opinion and contentious thought,

Or aught of heavier or more deadly weight,

In trivial occupations, and the round

Of ordinary intercourse.

They are also - and this is a point that I shall want to say more about - crucial to motivation; for they have

A virtue, by which pleasure is enhanced,

That penetrates, enables us to mount,

When high, more high, and lifts us up when fallen.

This idea that the power of epiphany is such as to suffuse the rest of our lives, even when we are far from the epiphanic moment itself, is at least echoed in Wordsworth's famous claim that poetry "takes its origin from emotion recollected in tranquillity" (Wordsworth 2013, 111).

It is there, too, in Wordsworth's best known poem of all - which is my fourth example. "Daffodils" (Wordsworth 1984, $303 \mathrm{f}$.) is one of the most shop-worn items in the entire canon of English poetry, but its sheer familiarity must not be allowed to dull our awareness that this too records both an epiphany, and the afterlife of that epiphany:

I gazed - and gazed - but little thought

What wealth the show to me had brought:

10 Wordsworth, "The tables turned", stanza 7: "Sweet is the lore which Nature brings; /Our meddling intellect/ Mis-shapes the beauteous forms of things; / - We murder to dissect." (Wordsworth 1984, 131).

11 John Keats, Letter to his brothers, 22.12.1817, in Keats $(1925,48)$. 
For oft, when on my couch I lie

In vacant or in pensive mood,

They flash upon that inward eye

Which is the bliss of solitude;

And then my heart with pleasure fills,

And dances with the daffodils.

It wasn't just that the daffodils were an epiphany - or the occasion of an epiphany - for Wordsworth at the particular time that he saw them. More than that, his vision of the daffodils had exactly the "renovating virtue" that the excerpt from The Prelude speaks of above, the power "whence... our minds/ are nourished and invisibly repaired", even when we are in the midst of "trivial occupations, and the round of ordinary intercourse". It is not the whole truth, but it is an important part of the truth, to say that epiphanies are defined contrastively. For pretty well everyone who writes or thinks about - or experiences - epiphanies, the epiphanic stands out against the background of the un-epiphanic.

Hopkins too, to come back to him, wrote supremely well about this often stark contrast between epiphany and afterwards; perhaps best of all in the almost perfect desolation of his last sonnet, "To Robert Bridges" (Hopkins 1967, 108). Here again his leading image is a sexual one, though differently from and more explicitly than "The Windhover":

The fine delight that fathers thought; the strong

Spur, live and lancing like the blowpipe flame,

Breathes once and, quenchèd faster than it came,

Leaves yet the mind a mother of immortal song.

Nine months she then, nay years, nine years she long

Within her wears, bears, cares and combs the same;

The widow of an insight lost she lives, with aim

Now known and hand at work now never wrong.

Sweet fire the sire of muse, my soul wants this:

I want the one rapture of an inspiration.

$\mathrm{O}$ then if in my lagging lines you miss

The roll, the rise, the carol, the creation,

My winter world, that scarcely breathes that bliss

Now, yields you, with some sighs, our explanation.

Though Hopkins never (to my knowledge) pre-empts James Joyce in actually using the word "epiphany" for what he here calls "the one rapture of an inspiration", at points like this he almost could have. It could not be plainer that here Hopkins, Murdoch, and Wordsworth are all talking about the same thing. Or as we should perhaps say, with proper caution observed and a nod ahead to the tasks of philosophical analysis that I am, as yet, only building towards, approximately the same thing. Cautious or not, it is not hard for us to see that when Hopkins writes about "sweet fire the sire of muse", about the moment of rapture that transfigures all around it, reaching even into the "winter world" of Hopkins" final illness, where he wrote this last poem - that he too is writing about epiphany, and the loss of epiphany. 
Is C.S. Lewis talking about epiphanies, when he describes the experiences of what he refers to as "Joy" that are central to his memoir of his own childhood and early years, Surprised by Joy? I think the answer is Yes, but clearly the point might be disputed. For Lewis's Joy has a more specific structure than anything that is in common between the epiphanies that I have described so far; and Joy seems, in itself, to be a response to certain kinds of epiphany rather than itself an epiphany. Still, having marked these differences, I think we can proceed on the assumption that when Lewis experienced Joy, it was because he had had (or was having) an epiphany. One reason why that assumption is a safe one is because of Lewis's own, eventual, understanding of the nature of Joy.

More about that eventual understanding when we get to it. How might we understand Joy to start with? Lewis gives various examples of the phenomenon drawn from his own early childhood:

The first is itself the memory of a memory. As I stood beside a flowering currant bush on a summer day there suddenly arose in me without warning, and as if from a depth not of years but of centuries, the memory of that earlier morning at the Old House when my brother had brought his toy garden into the nursery. It is difficult to find words strong enough for the sensation which came over me; Milton's "enormous bliss" of Eden (giving the full, ancient meaning to "enormous") comes somewhere near it. It was a sensation, of course, of desire; but desire for what? Not, certainly, for a biscuit-tin filled with moss, nor even (though that came into it) for my own past. Iou lian potho ${ }^{12}-$ and before I knew what I desired, the desire itself was gone, the whole glimpse withdrawn, the world turned commonplace again, or only stirred by a longing for the longing that had just ceased. It had taken only a moment of time; and in a certain sense everything else that had ever happened to me was insignificant in comparison. (Lewis 1955, 18)

Another of Lewis's childhood examples is reading Longfellow's English versions of the Norse myths. He tells us his response was pleasant but superficial at first and then

...quite different from such pleasures, and like a voice from far more distant regions, there came a moment when I idly turned the pages of the book and found the unrhymed translation of Tegners Drapa and read

\footnotetext{
12 "Alas, I long too much." The Greek phrase is inscribed on the sitter's hat-brim in Moretto's picture Portrait of a Young Man (National Gallery, London). The phrase was evidently well-known in late-Victorian and Edwardian England, partly because it is a pun. Cf. Cook (1922, 269): "On his cap is a label inscribed เov $\lambda \iota \alpha v \pi \circ \theta \omega$, which being literally interpreted means 'Alas, I desire too much!' - an inscription which accords with the yearning upward gaze and the pose selected by the painter. But the motto has also a punning reference. Reading the two first words as one, it becomes a further pun on the last word, 'Julia Potho'... The Potho or Pozzo family was well known at the time in Brescia. Francesco dal Pozzo, $3^{\text {rd }}$ Marquis of Ponderano (born 1494), had as his first-born a daughter Julia. She became the wife of Giacomo Gromo, Signor di Ternengo." (My thanks to Michael Trapp for helping me find this reference.).
} 
I heard a voice that cried

"Balder the beautiful

Is dead, is dead"13

I knew nothing about Balder; but instantly I was uplifted into huge regions of northern sky, I desired with sickening intensity something never to be described (except that it is cold, spacious, severe, pale, and remote) and then, as in the other examples, found myself at the very same moment already falling out of that desire and wishing I were back in it. (Lewis 1955, 19-20)

Lewis generalises from his examples to produce his first clear account of what he means by Joy $(1955,20)$ :

I will only underline the quality common to [these] experiences: it is that of an unsatisfied desire which is itself more desirable than any other satisfaction. I call it Joy, which is here a technical term and must be sharply distinguished both from Happiness and from Pleasure. Joy (in my sense) has indeed one characteristic, and one only, in common with them: the fact that anyone who has experienced it will want it again. Apart from that, and considered only in its quality, it might almost equally well be called a particular kind of unhappiness or grief. But then it is a kind we want. I doubt whether anyone who has tasted it would ever, if both were in his power, exchange it for all the pleasures in the world. But then Joy is never in our power and pleasure often is.

This makes Lewis's Joy sound rather like the restless, mysterious, intense but unfocused longing that the Germans call Sehnsucht (and that the Greeks call pothos). That impression is confirmed when we read on in Surprised by Joy to the time later in his youth - Lewis calls it "renaissance" - when the experience of Joy came back to him after what he recalls as some years of bleakness $(1955,62 \mathrm{f}$.):

This long winter broke up in a single moment... I can lay my hand on the very moment; there is hardly any fact I know so well, though I cannot date it... My eye fell upon a headline and a picture, carelessly, expecting nothing. A moment later, as the poet ${ }^{14}$ says, "the sky had turned round"... What I had read was the words Siegfried and the Twilight of the Gods. What I had seen was one of Arthur Rackham's illustrations to that volume. I had never heard of Wagner, nor of Siegfried. I thought the Twilight of the Gods meant the twilight in which the gods lived... [But] pure "Northernness" engulfed me: a vision of huge, clear spaces hanging above the Atlantic in the endless twilight of Northern summer, remoteness, severity... And almost at the same time I knew that I had met this before... that Siegfried... belonged to the same world as Balder... And with that plunge back into my own past there arose at once, almost like heartbreak, the memory of Joy itself, the knowledge that I had once had what I had now lacked for years, that I was returning at last from exile and desert lands to my own

\footnotetext{
13 In Longfellow $(1849,77)$.

14 "The poet" here is Lewis's own friend Charles Williams, in his Arthurian poem "Palomides before his christening" (Williams 1938, 64).
} 
country; and the distance of the twilight of the Gods and the distance of my past Joy, both unattainable, flowed together into a single, unendurable sense of desire and loss, which suddenly became one with the loss of the whole experience, which... had already vanished, had eluded at me at the very moment when I could first say It is. And at once I knew (with fatal knowledge) that to 'have it again' was the supreme and only important object of desire.

Many philosophical outlooks seem at least biographically to rest upon particular vivid experiences, as utilitarianism might rest upon a sudden awareness of the reality of animal suffering. Certainly here, there seems little doubt that it was this sort of experience that laid the foundations for Lewis's later preoccupations, both academic and authorial.

However, the surprise in Surprised by Joy is that Joy falls by the wayside: by the end of Lewis's narrative, it has quite lost its central and preoccupying place in his own life. Joy is no longer central to his thinking about life and literature in the way that it clearly was immediately after the experience just recounted. On the very last page of Surprised by Joy, rather bathetically in the light of what has come before, we read this $(1955,190)$ :

But what, in conclusion, of Joy? For that, after all, is what the story has mainly been about. To tell you the truth, the subject has lost nearly all interest for me since [...]. I cannot, indeed, complain, like Wordsworth, that the visionary gleam has passed away. I believe (if the thing were at all worth recording) that the old stab, the old bitter-sweet, has come to me as often as sharply since [...] as at any time of my life whatever. But I now know that the experience, considered as a state of my own mind, had never had the kind of importance I once gave it. It was valuable only as a pointer to something other and outer.

And what is this "something other and outer"? The answer is given in the two phrases I have deliberately plucked out of the quotation, both of them beginning with the word "since". Restored, the phrases are "since I became a Christian", and "since my conversion". As he explains rather earlier in the book, Lewis had come to believe that the experience that he called Joy was a signpost pointing us towards God. ${ }^{15}$

The train of thought that, Lewis says, led him to this belief began from a distinction made by Samuel Alexander in Space, Time, and Deity (Alexander 1920). Alexander calls it the distinction between "enjoyment" and "contemplation": we might call it the distinction between being affected by some object that you are attending to, and attending to the effect that the object has on you rather than to the object itself. As Lewis explains $(1955,174)$ :

\footnotetext{
15 There is probably the further mild joke in the offing that Lewis, by the time he wrote these words, had set aside Joy the experience, for Joy the wife (Helen Joy Davidman): like the book's title, its ending is among other things a compliment to her. The book's title, incidentally, is the first three words of a fine sonnet by Wordsworth (1815), about the loss of epiphanic experience. Perhaps there is a hint here that Lewis is only affecting nonchalance about the passing of such experience from a central place in his life.
} 
It seemed to me self-evident that one essential property of love, hate, fear, hope, or desire was attention to their object. To cease thinking about or attending to the woman is, so far, to cease loving; to cease thinking about or attending to the dreaded thing is, so far, to cease being afraid. But to attend to your own love or fear is to cease attending to the loved or dreaded object... You cannot hope and also think about hoping at the same moment; for in hope we look to hope's object and we interrupt this by (so to speak) turning round to look at the hope itself.

Applied to Joy this distinction had, Lewis found, momentous consequences (1955, 175f.):

I saw that all my waitings and watchings for Joy, all my vain hopes to find some mental content on which I could, so to speak, lay my finger and say, "This is it," had been a futile attempt to contemplate the enjoyed. All that such watching and waiting ever could find would be either an image... or a quiver in the diaphragm... these images or sensations... were merely the mental track left by the passage of Joy - not the wave but the wave's imprint on the sand. The inherent dialectic of desire itself had in a way already shown me this; for all images and sensations, if idolatrously mistaken for Joy itself, soon honestly confessed themselves inadequate, all said in the last resort, "It is not I. I am only a reminder. Look! Look! What do I remind you of?"

And hence Lewis's theistic conclusion - a conclusion which I think also vindicates my earlier claim that Lewis's Joy is indeed a kind of epiphany, and not just an experience of an inner feeling (1955, 175f.):

...there was no doubt that Joy was a desire... but a desire is turned not to itself but to its object. Not only that, but it owes all its character to its object... The form of the desired is in the desire. It is the object which makes the desire harsh or sweet, coarse or choice, "high" or "low"... I had been wrong in supposing that I desired Joy itself. Joy itself, considered simply as an event in my own mind, turned out to be of no value at all. All the value lay in that of which Joy was the desiring. And that object, quite clearly, was no state of my own mind or body at all... I thus understood that in deepest solitude there is a road right out of the self, a commerce with something which, by refusing to identify itself with any object of the senses, or anything whereof we have biological or social need, or anything imagined, or any state of our own minds, proclaims itself sheerly objective.

And so Lewis's road leads him, from the particular experiences of mysterious longing that he calls Joy, to what that longing is a longing for. With a little help from the absolute-idealist philosophy of F.H. Bradley that, at the time, he was teaching to Magdalen and Univ. undergraduates in Oxford, and also believed himself, he comes to think that the longing of Joy is always for the same thing, and that his various experiences all point in a single direction: towards the Absolute of which they are appearances. 
Joy was not a deception. Its visitations were rather the moments of clearest consciousness we had, when we became aware of our fragmentary and phantasmal nature and ached for that impossible reunion which would annihilate us or that self-contradictory waking which would reveal, not that we had had, but that we were, a dream. (Lewis 1955, 177)

And then Lewis later comes - in contrast to Bradley himself - to identify this Absolute with something in some ways utterly unlike it. The longing of Joy becomes a divine longing; because the hidden reality that Joy is a longing for - the "other and outer" of which Lewis speaks above - is, in the end, unmasked as nothing less than the Christian God.

This intellectual path from a variety of epiphanies to one God lying behind them all as their single source is, of course, one that plenty of others had trodden before Lewis. In particular, it is an Augustinian path, one that Augustine in the Confessions is taking from the moment he says, in the very first chapter, that "You made us for yourself, and our heart is restless till we find our rest in you". It can be argued that the central theme of the Confessions is exactly the one that I have just sketched the theme that all other desires have underlying them the desire for God himself; indeed, this has been argued, by Talbot Brewer (Brewer 2007) and by myself (in Chappell 2014, ch. 4). Such a unifying approach to epiphanic experiences is often found in the Bible too, from the moment when Jacob first exclaims "Surely God is in this place and I knew it not ... How awesome is this place! This is none other than the house of God, and this is the gate of heaven" (Genesis 28.6). That it is the same one God who underlies all the visible splendours of the world is clearly the psalmist's conviction, too, when he declares that "The heavens declare the glory of the Lord" (Psalm 8.1).

Thus epiphany is often understood as a veiled and indirect epiphaneia, revelation, of God; as it also is in T.S. Eliot's well-known poem "The Journey of the Magi" (a poem for Epiphany, i.e. the Christian festival that falls on January $6^{\text {th }}$ ) (Eliot 1952, 68). There are also plenty of cases where, on the contrary, epiphanies occur that are taken to be entirely un-veiled and direct revelations of God; perhaps Blaise Pascal's "Night of Fire", to pick one out of thousands, is the most famous of all. And so the theme of epiphany can modulate into the theme of religious experience; though I will not take quite that path here - not yet.

\section{5}

Hopkins, Murdoch, Wordsworth, Lewis: there is far more in common between their experiences than between their conceptualisations of those experiences. As Nicholas Lash puts it, "concepts divide, experience unites" (Lash 1988, 22).

So for instance, at one extreme, Murdoch connects epiphany with Buddhistic unselfing; at the other, Hopkins connects it with Scotistic selving. Wordsworth goes in another direction again, since he takes it (Prelude XII.221-223) that the key significance of his "spots of time" is to reveal 
to what point, and how,

The mind is lord and master - outward sense

The obedient servant of her will.

(Wordworth 1984, 565)

Wordsworth's direction here is towards what John Keats (in a letter to his friend Richard Woodhouse of 27.10.1818, cf. Keats 1925, 183-185) witheringly dubbed "the egotistical sublime": the idealist notion that everything in nature is just a cloudy image of Spirit. Keats is rude about this because, for one thing, his own inclination lies in the opposite direction, towards seeing the poet's experience of epiphany as something more like Murdochian unselving. A poet, Keats says in the same letter, "has no identity". Like the mirror at the beginning of Republic Book X, or indeed like Hamlet's mirror, "he is continually in for - and filling some other body": "he has no self... [as a poet] I have no nature." (These comparisons with Plato and Shakespeare are my own, not - so far as I know - Keats's.)

For what it's worth, I myself am rather on Keats's side in this particular dispute. My own inclination, like Bishop Butler's, is to see every thing as itself, and not as a symbol of some other thing; to separate out, to particularise, not to unite everything under one vast frame of cloudy speculation. To that extent I find myself resistant, for instance, to what Nietzsche might have called Lewis's monotonotheistic tendency to see all Joy as having no merit in itself, as pointing solely and simply to God. So I would take it to be a very serious criticism of Wordsworth - if it were true that so far from being truly a poet of nature, he in fact sees nature as no more than a prompt-book to his own inner ruminations.

But on the whole I think Keats's criticism is untrue, because it makes Wordsworth, to his detriment, more consistent than he actually is. If Wordsworth had really and consistently seen the outer world as nothing but secondary, as a mere assemblage of props to the psychodrama of his mind, then it is hard to see how he could have avoided writing about nature in vague pallid lifeless generalities. And despite his frequent bouts of indulgence in headily world-spirituous speculation, that is no more how Wordsworth writes about nature than it is (to cite another deeply inconsistent artist) how Tolstoy writes about the Rostovs. Wordsworth is a true poet, and therefore of the particularising party without knowing it; and so he writes in fetters when he writes of "the eternal spirit", but at liberty when he writes of dawn on Snowdon or the moonlight on Cartmel Sands.

However, it is a side-issue who is right in Keats's disagreement with Wordsworth about the conflict between experience and the theorising of experience. The main point for the moment is only that there is this conflict, and that perennially writers are closer together in what they experience than in how they make conceptual sense of it.

That main point could not be more obvious in the case of my final example in this paper, James Joyce, who gives (probably without actually endorsing) a theoretical account of what goes on in the experiences that he calls epiphanies which is different from anything else we have seen so far. It is least dissimilar, perhaps, to Gerard Manley Hopkins' account; more below on the similarities and contrasts between them. 
James Joyce is of particular interest here anyway, because he is the writer who first coined our term "epiphany". His clearest exposition of what he means by the term is in his fragmentary autobiographical work Stephen Hero, the prototype of A Portrait of the Artist as a Young Man. ${ }^{16}$ Joyce's exposition begins like this:

A young lady was standing on the steps of one of those brown brick houses which seem the very incarnation of Irish paralysis. A young gentleman was leaning on the rusty railings of the area. Stephen as he passed on his quest heard the following fragment of colloquy out of which he received an impression keen enough to afflict his sensitiveness very severely.

The Young Lady - (drawling discreetly) ...O, yes ...I was... at the ... cha... pel... The Young Gentleman - (inaudibly)... I ... (again inaudibly)... I ...

The Young Lady - (softly) ...O ...but you're ...ve ... ry ...wick ... ed.

This triviality made him think of collecting many such moments together in a book of epiphanies. By an epiphany he meant a sudden spiritual manifestation, whether in the vulgarity of speech or of gesture or in a memorable phase of the mind itself. He believed that it was for the man of letters to record these epiphanies with extreme care, seeing that they themselves are the most delicate and evanescent of moments.

(Joyce 1944, 216)

So far - you may be forgiven for thinking - so unclear. Dedalus is, as we might expect, a riddler. There is a certain studied inexplicitness about much of Joyce's writing, including "the book of epiphanies" that actually resulted from the resolution recorded here, namely Dubliners (complete by 1905, unpublished until 1914). Joyce's lack of explicitness is partly a tendency to prefer showing to telling to such an extent that the reader is often not too sure what he is being shown; and it is partly because of Joyce's fastidious (perhaps over-fastidious) anti-Victorian rejection of sentimentality. It is interesting, and revealing, that one of the reasons why Joyce replaced Stephen Hero with A Portrait of the Artist as a Young Man, and was so reluctant to publish the earlier version, is apparently that he felt Stephen Hero "gave too much away".

"A sudden spiritual manifestation" is a less than exact expression; nor is it obvious at first sight, from this dialogue between the Young Lady and the Young Gentleman, what exactly it was about the whispered exchange that so captured Stephen Dedalus' attention. We can guess if we like that that exchange had an enchantingly romantic air, a captivating hint of impropriety; but that will be a guess, and no more. But then, Joyce tells us, in the quotation above, that epiphanies are "the most delicate and evanescent of moments". And in the very next lines, Joyce does have Stephen Dedalus present the view as clearly and explicitly as he can.

16 Stephen Hero was written 1904-1906, but only published posthumously in 1944; Portrait was published in 1916. 
He told Cranly that the clock of the Ballast Office was capable of an epiphany. Cranly questioned the inscrutable dial of the Ballast Office with his no less inscrutable countenance:

-Yes, said Stephen. I will pass it time after time, allude to it, refer to it, catch a glimpse of it. It is only an item in the catalogue of Dublin's street furniture. Then all at once I see it and I know at once what it is: epiphany.

-What?

-Imagine my glimpses at that clock as the gropings of a spiritual eye which seeks to adjust its vision to an exact focus. The moment the focus is reached the object is epiphanised. It is just in this epiphany that I find the third, the supreme quality of beauty.

(Joyce 1944, 216-7)

The bovine Cranly has little enough idea what Stephen is saying to him. But Joyce's readers - perhaps under an implicit challenge to prove they are better than bovine - may begin to get the idea by this point. They may see connections with, for example, William Blake's famous idea of seeing "a world in a grain of sand". ${ }^{17}$ It is important to what Stephen is saying that even the most banal or workaday object can be "epiphanised", made cause for, or into, an epiphany: even the clock of the Dublin Harbour Ballast Office Also, and perhaps even more obviously, Stephen is telling us that epiphany is focus, clear and fully precise seeing. Compare Iris Murdoch's proposal to introduce into our moral thinking

the idea of attention, or looking... I can only [make the moral choices that so interest most moral philosophers] within the world I can see, in the moral sense of 'see' which implies that clear vision is a result of moral imagination and moral effort. (Murdoch 1970: 36-37)

There is a third point that Stephen makes in this passage: that there is a constitutive connection between epiphany and beauty. What he says about this, a couple of paragraphs later, draws very directly on Aquinas' three-part definition (or perhaps we should more loosely say "account") of beauty at Summa Theologiae 1a.39.8: ${ }^{18}$

-You know what Aquinas says: The three things requisite for beauty are, integrity, a wholeness, symmetry and radiance. Some day I will expand that sentence into a treatise...

In fact, in the words that immediately follow, Stephen already comes close to producing, or at least to epitomising, this treatise; as far as I know, as close as James Joyce ever came. Stephen continues:

\footnotetext{
17 William Blake, "Auguries of innocence": lines 1-4: "To see a World in a Grain of Sand / And a Heaven in a Wild Flower / Hold Infinity in the palm of your hand / And Eternity in an hour.".

18 Aquinas' actual words are: Nam ad pulchritudinem tria requiruntur. Primo quidem, integritas sive perfectio: quae enim diminuta sunt, hoc ipso turpia sunt. Et debita proportio sive consonantia. Et iterum claritas, unde quae habent colorem nitidum, pulchra esse dicuntur. ("Because for beauty three things are required. First, unity or completeness; for if a thing's unity or completeness is lessened, by that very change the thing becomes less beautiful. Secondly, due proportion or coherence. And thirdly, distinctness, clarity - whence things that are bright-coloured are said to be beautiful.")
} 
Consider the performance of your own mind when confronted with any object, hypothetically beautiful. Your mind to apprehend that object divides the entire universe into two parts, the object, and the void which is not the object. To apprehend it you must lift it away from everything else: and then you perceive that it is one integral thing, that is $a$ thing. You recognise its integrity... That is the first quality of beauty: it is declared in a simple sudden synthesis of the faculty which apprehends.

We saw above how the moment of epiphany is very often defined as such, at least partly, by its contrast with the stretches of unepiphanic time that surround it. Likewise in Dedalus' description here, the object of epiphany (as it is going to be, though at this point in his account it isn't yet) is defined by its contrast with the expanses of unepiphanic existents that surround it. That void may, of course, be no more than a function of the attention that is involved in epiphany, or the experience of epiphany; it is familiar how attending closely to one thing can make everything else around it almost invisible to us. At any rate it seems clear that it makes more sense to read Dedalus' words here as phenomenology rather than as metaphysics. He doesn't mean that everything around the epiphanic object really is formless void; he means that this is how it is bound to seem during the first of the three stages that bring us to epiphany.

Writing this in about 1905, Joyce could not have been thinking of Gerard Manley Hopkins' writings on "instress" and "inscape", not at least as we have them, because these were unpublished until 1937. ${ }^{19}$ However, if not of Hopkins' writings, he could certainly have been thinking of Hopkins' ideas: Hopkins was Professor of Greek at University College Dublin from 1884 till his death in 1889, and Joyce was a student at University College Dublin from 1901 to 1904, so it is quite possible that Joyce came across Hopkins' views in lectures or classes or discussions. In any case, the parallel is a natural one for us to draw. Hopkins' idea was that God's creative action involved pressing form into matter (this pressing is instress), with the result that the matter becomes shaped by that form (this being-shaped is inscape). ${ }^{20}$ We can understand artistic vision or experience as either the detection of inscape in this sense, or indeed as the imposition of inscape upon what is already so instressed as to be 'readable' in this way. Now Hopkins, of course, claimed Scotus as his authority for these ideas; but it is obvious from Joyce's just-quoted remarks how easily Hopkins (or Scotus) could have derived a very similar idea from Aquinas. The "recognition of an object's integrity" in a "simple sudden synthesis" of understanding or apprehension seems to be very close indeed to what Hopkins means when he talks of inscape (or of discerning inscape).

But this is, as I've been saying, only the first of three stages that Dedalus distinguishes in the process that leads to epiphany. The second stage is what he describes

\footnotetext{
19 See Hopskins (1937).

20 In The Doors of Perception (e.g. Huxley 1954, 25, 27) Aldous Huxley uses the word "inscape" roughly as if it meant "inner landscape". Whether Huxley's use is a separate and independent coinage, or whether he supposes, improbably, that he is using the word in Hopkins' sense, I am unsure.
} 
next. In a way it is just what we would expect it to be, given that the first stage, as Dedalus has just told is, is a synthesis (1.c.):

What then? Analysis then. The mind considers the object in whole and in part, in relation to itself and to other objects, examines the balance of its parts, contemplates the form of the object, traverses every cranny of the structure. So the mind receives the impression of the symmetry of the object. The mind recognises that the object is in the strict sense of the word, a thing, a definitely constituted entity. You see?

In the first phase of the kind of attention that Dedalus is describing, the experience of beauty, the mind grasps the object together, as a unity: this is what Aquinas calls integritas sive perfectio, "unity or completeness" as I think we should probably translate it here. In the second it grasps how that unity is composed - by analysing it or taking it apart, as a painter might study anatomy to learn how to depict the human body: by learning to see how its parts contribute to its unity. This is what Aquinas calls debita proportio sive consonantia, "due proportion or coherence".

What about the third, for which Aquinas' word is claritas? Dedalus goes on:

...For a long time I couldn't make out what Aquinas meant. He uses a figurative word (a very unusual thing for him) but I have solved it. Claritas is quidditas. After the analysis which discovers the second quality the mind makes the only logically possible synthesis and discovers the third quality. This is the moment which I call epiphany. First we recognise that the object is one integral thing, then we recognise that it is an organised composite structure, a thing in fact: finally, when the relation of the parts is exquisite, when the parts are adjusted to the special point, we recognise that it is that thing which it is. Its soul, its whatness, leaps to us from the vestment of its appearance. The soul of the commonest object, the structure of which is so adjusted, seems to us radiant. The object achieves its epiphany.

(Joyce 1944, 216-218)

In the first phase of Dedalus' dialectic of the experience of beauty we grasp that some thing is $a$ thing; in the second phase, how the thing that it is, is composed; and in the third, that it is this thing. Or to put it another way: first we see its simplicity; then we see its complexity; then we see the rightness of its being the very thing it is. And this third phase, says Dedalus, "is the moment which I call epiphany".

How then should we take this complex neo-Thomist theory of the epiphany? Various considerations immediately suggest the answer "Not at face value". For one thing, given Joyce's personal beliefs about religion, he is, to put it mildly, not the most obvious author to look to as a purveyor of neo-Thomistic philosophy. $A$ Portrait of the Artist as a Young Man is the final version of what Joyce was trying to do in Stephen Hero, and it includes both a later version of the neo-Thomist theory of beauty $(1943,229 \mathrm{ff}$.) and also a fierce and graphic sermon on hell (1943, 136ff.); there is no more reason to see the theory of beauty as representing Joyce's own views than there is the sermon on hell.

For another, Joyce's own main example of an epiphany in Stephen Hero obviously does not fit the pattern that Dedalus expounds here. With the whispering couple on 
the brownstone steps, what is the movement through integritas and consonantia to claritas? There is, apparently, none, and it is hard to see how there could possibly be meant to be; apart from anything else, the dialectic that Dedalus describes is a pattern made for objects, not events. The same applies to Dubliners, if Dubliners is indeed a book of epiphanies - which, among other descriptions, does seem right. Dubliners may well be said to collect "sudden spiritual manifestations", often too of a very delicate and evanescent sort; but it is far from obvious that what it collects has anything like the three-part structure that Dedalus is describing.

Thus, I suspect, the truth about the neo-Thomist theory that Stephen Dedalus offers in both Stephen Hero and Portrait is that, like much else in the two books, it is offered mainly as an example of Joyce's own younger mind at work. Not, of course, that its philosophical (or literary) interest depends entirely on Joyce's intentions in presenting it. But it does seem important to the assessment of the neoThomist theory that Joyce sees it as something that he has outgrown, something that could not be right just as he presents it, any more than the sermon on hell could be. Perhaps part of the reason why is simply because it is a theory: the neo-Thomist tripartite account of beauty is very neat and very scholarly, but the only way to make it even look like it could have any very general application is to distort the phenomena. And that, if I may put words into his mouth, is something that Joyce is no keener to do than I am.

It also seems important that Joyce is constantly presenting us, both in these books and in Dubliners and indeed throughout his writing, with what he takes to be epiphanies that are not distortions of the phenomena. These, as already suggested, are epiphanies that count as such in the much wider and looser sense that they count as "sudden spiritual manifestations" that are also "the most delicate and evanescent of things". One example is the gleam of the coin in Corley's hand at the end of "Two Gallants" (Joyce 1916, 70). Another (which I'll end with) is the night-time snow that, so unusually, is "general over all Ireland" in the subtly rhapsodic lines, and the "slow swoon", that come at the end of "The Dead" (Joyce 1916, 277f.):

A few light taps upon the pane made him turn to the window. It had begun to snow again. He watched sleepily the flakes, silver and dark, falling obliquely against the lamplight. The time had come for him to set out on his journey westward. Yes, the newspapers were right: snow was general all over Ireland. It was falling on every part of the dark central plain, on the treeless hills, falling softly upon the Bog of Allen and, farther westward, softly falling into the dark mutinous Shannon waves. It was falling, too, upon every part of the lonely churchyard on the hill where Michael Furey lay buried. It lay thickly drifted on the crooked crosses and headstones, on the spears of the little gate, on the barren thorns. His soul swooned slowly as he heard the snow falling faintly through the universe and faintly falling, like the descent of their last end, upon all the living and the dead.

Open Access This article is distributed under the terms of the Creative Commons Attribution 4.0 International License (http://creativecommons.org/licenses/by/4.0/), which permits unrestricted use, distribution, and reproduction in any medium, provided you give appropriate credit to the original author(s) and the source, provide a link to the Creative Commons license, and indicate if changes were made. 


\section{References}

Alexander, Samuel. 1920. Space, Time, and Deity: the Gifford Lectures at Glasgow University 1916-1918. London: Macmillan.

Balthasar, Hans Urs von. 1988. Theo-Drama. London: Ignatius Press.

Brewer, Talbot. 2007. Three dogmas of desire. In Values and Virtues. Ed. T. Chappell, 257-284. New York: Oxford University Press.

Broad, C.D. 1949. The Relevance of Psychical Research to Philosophy. Philosophy 24: 291-309.

Chappell 2014: Sophie Grace Chappell, Knowing What To Do. Oxford: Oxford University Press.

Chappell, T. 2011. Glory as an ethical idea. Philosophical Investigations 34(2): 105-134.

Collingwood 1939: R.G. Collingwood, An Autobiography. Oxford: Oxford University Press.

Cook, E.T. 1922. A Popular Handbook of the National Gallery. Vol. 1. London: Macmillan \& Co.

Danto, Arthur. 1983. The Transfiguration of the Commonplace: a philosophy of art. Cambridge, MA: Harvard University Press.

Eliot, George. 1872. Middlemarch. London: William Blackwood.

Eliot, George. 1952. Complete Poems and Plays. New York: Harcourt Brace.

Griffiths, Bede. 1979. The Golden String. London: Fount.

Hegel, G.W.F. 1835. Lectures on Aesthetics. Ed. M. Inwood. London: Penguin.

Hopkins, Gerard Manley. 1937. The Note-Books and Papers of Gerard Manley Hopkins. Ed Humphry House. Oxford: Oxford University Press.

Hopkins, Gerard Manley. 1967. Poems. $4^{\text {th }}$ edition. Ed. Helen Gardner. Oxford: Oxford University Press. Huxley, Aldous. 1954. The Doors of Perception. London: Chatto \& Windus.

James, William. 1890. The Principles of Psychology. New York: Dover.

Joyce, James. 1916. Dubliners. London: Grant Richards.

Joyce, James. 1943. A Portrait Of The Artist As A Young Man. London: Jonathan Cape.

Joyce, James. 1944. Stephen Hero . Ed. T. Spencer. London: Paladin.

Keats, John. 1925. Letters of John Keats to His Family and Friends. Ed. Sidney Colvin. London: Macmillan $\&$ Co.

Larkin, Philip. 1982. Interview with Paris Review. In Required Writing, 57-76. London: Faber \& Faber.

Lash, Nicholas. 1988. Easter in Ordinary. London: SCM Press.

Lewis, C.S. 1955. Surprised by Joy. London: Geoffrey Bles.

Longfellow, H.W. 1849. The Seaside and the Fireside. Boston: Ticknor, Reed, and Fields.

McFarquhar, Melissa. 2018. The mind-expanding ideas of Andy Clark. The New Yorker, April 2, 2018 Issue.

Murdoch, Iris. 1970. The Sovereignty of Good. Oxford: Blackwell.

Trungpa, Chögyam. 1973. Cutting Through Spiritual Materialism. Shambala: Boston and London.

Wells, Sam. 2004. Improvisation. London: Baker Publishing.

Williams, Charles. 1938. Taliessin Through Logres and The Region of the Summer Stars. Oxford: Oxford University Press.

William Wordsworth, The Prelude, 1815. Many editions. The one I use is the Stephen Gill edition, OUP, 1991.

Wordsworth, William. 1984. The Major Works, including The Prelude. Ed. Stephen Gill. Oxford: Oxford University Press.

Wordsworth, William. 2013. Lyrical Ballads, 1798 and 1802. Ed. Fional Stafford. Oxford: Oxford University Press. 